\title{
RELATIONS BETWEEN THE CZECH LEGION'S REPRESENTATIVES AND THE OPPOSING POLITICAL FORCES IN THE VOLGA REGION: FROM NEGOTIATIONS TO WAR ${ }^{1}$
}

\author{
Berik K. Dulatov \\ Ostrava University, Ostrava, Czech Republic
}

\begin{abstract}
The article deals with the issues of mutual relations of Czechoslovak legionaries with local executive authorities in the territory of the Volga region and the Southern Urals. Initially, Czechs, as citizens of AustriaHungary, were involved in the war against the Russian Empire according to military duty. At a subconscious level, Czechs and Slovaks felt ethnic solidarity and closeness with the Slavic peoples. At the beginning of the Civil War, according to the established Soviet tradition, they were involved in the Czech (Czechoslovak) legion, which conducted military and ideological war against the Soviet regime. In this perspective, there is a need to study the reasons for the participation of Czechs in the so-called Revolt of the Czechoslovak Legion, to reveal the factors that led to the beginning of the Czech rebellion and to name the initiators of this event. Of considerable interest are the problems of studying political attitudes and sympathies of Czech prisoners of war to events on the territory of the empire on the eve of the outbreak of the revolution and in the course of the Civil War. The problem of the participation of Czechs and Slovaks in the Red Army, and in other military formations that are ideologically close to the Soviet regime, are also understudied in historiography.

On the basis of the archival sources, the author concludes that the public attitude towards Czechs and Slovaks during the Civil War was ambiguous. Under certain historical conditions, a certain part of these prisoners did not have any illusions of an unhindered exit from the war-torn Russia, and only participation in any of the warring parties as servicemen could, to some extent, facilitate their departure for the ethnic homeland. Therefore, many servicemen were at the crossroads, perhaps having no ideological convictions, but striving for either a departure abroad or a stay in their new homeland.
\end{abstract}

Key words: Czechoslovak National Council, Czechoslovak Corps, Civil War in Russia, Syzran, Penza.

Citation. Dulatov B.K. Relations between the Czech Legion's Representatives and the Opposing Political Forces in the Volga Region: from Negotiations to War. Vestnik Volgogradskogo gosudarstvennogo universiteta. Seriya 4, Istoriya. Regionovedenie. Mezhdunarodnye otnosheniya [Science Journal of Volgograd State University. History. Area Studies. International Relations], 2018, vol. 23, no. 2, pp. 127-139 (in Russian). DOI: https://doi.org/10.15688/jvolsu4.2018.2.10

\section{ОТНОШЕНИЕ ПРЕДСТАВИТЕЛЕЙ ЧЕШСКОГО ЛЕГИОНА С ПРОТИВОБОРСТВУЮЩИМИ ПОЛИТИЧЕСКИМИ СИЛАМИ В ПОВОЛЖЬЕ: ОТ ПЕРЕГОВОРОВ К ВОЙНЕ ${ }^{1}$}

\author{
Берик Кайратович Дулатов \\ Остравский университет, г. Острава, Чешская Республика
}

Аннотация. В статье актуализированы вопросы взаимоотношений чехословацких легионеров с местными исполнительными органами на территории Поволжья и Южного Урала. Первоначально чехи, как субъекты Австро-Венгрии, были вовлечены в войну против Российской империи в соответствии с военной 
обязанностью. На подсознательном уровне чехи и словаки чувствовали этническую солидарность и близость со славянскими народами. В начале Гражданской войны чехи и словаки принимали участие в антибольшевистском восстании в составе чехословацкого легиона. В статье на основе архивных материалов предпринимается попытка выяснить причины участия чехов в так называемом «белочешском мятеже», выявить факторы, которые привели к началу восстания, установить инициаторов этого события. Делается вывод, что отношение общественности к чехам и словакам во время Гражданской войны было неоднозначным.

Ключевые слова: Чехословацкий национальный совет, Чехословацкий корпус, Гражданская война в России, Сызрань, Пенза.

Цитирование. Дулатов Б. К. Отношение представителей Чешского легиона с противоборствующими политическими силами в Поволжье: от переговоров к войне // Вестник Волгоградского государственного университета. Серия 4, История. Регионоведение. Международные отношения. - 2018. - Т. 23, № 2. - С. 127 139. -DOI: https://doi.org/10.15688/jvolsu4.2018.2.10

В современный период интеграции в мировое пространство постсоветских государств актуализируется проблема изучения исторического прошлого народов и этнических групп, проживающих в огромной территориальной зоне Северного Казахстана, Приуралья, Поволжья, Сибири. В частности, научный интерес вызывает история чехов и чешских граждан, которые в результате участия в Первой мировой войне оказались за пределами своей родины. Данная тема актуализируется также в преддверии 100-летнего юбилея Гражданской войны в России. Большой интерес представляют проблемы изучения политических взглядов и симпатий представителей чешского этноса, отношение военнопленных и легионеров к событиям на территории Российской империи накануне начала революции и в годы Гражданской войны, их взаимоотношения с представителями различных государственных органов и правительств, функционировавших в период с 1917 по 1920-е годы.

Вопросы изучения чехословацкого мятежа и истории чехов неоднократно были под пристальным вниманием исследователей в советской, современной российской и зарубежной историографии. Одним из первых трудов, посвященных истории чехов и словаков, является работа бывшего корреспондента «Русских ведомостей» Н.С. Каржанского [11]. В данной работе автор поэтапно изучил эволюцию взаимоотношений чехов и словаков с представителями царского и Временного правительств и большевиков.

Другим важным трудом является работа В.С. Драгомирецкого [9]. Автор уделяет внимание развитию межславянских отношений, рассматривает историю Чехословацкого леги- она, его формирование и деятельность как военного подразделения на территории России.

В историографии периода 1960-1980-х гг. выделяется работа А.Х. Клеванского [12]. Автор рассмотрел некоторые вопросы развития чешского национального движения и в этом аспекте положение чешских и словацких военнопленных в России.

В историографии 1990-х гг. следует упомянуть работу М.Д. Савваитовой [24]. В данном исследовании затрагивается круг вопросов, связанных с чехословацкими воинскими формированиями в России и проблемой их комплектования из пленных чехов и словаков.

Из зарубежной историографии, прежде всего, нужно отметить многотомный труд В.М. Фика. В 4-м томе речь идет, в частности, о политических группировках, известных военных лидерах и их взаимосвязи с чешскими гражданами в период их нахождения в Сибири [34].

Еще одним исследованием на данную тему являются работы Д. Вахи [36; 37], в которых рассматриваются причины вступления чешских граждан в легион, история его формирования, повседневная деятельность, описаны такие проблемы, как проживание, питание, формы проведения досуга и контактов с местным населением. Автор повествует о трагических событиях периода нахождения чехов на территории Российской империи, характеризует формы их участия в политических событиях того времени, рассказывает о борьбе со смертью, в том числе от полученных травм и болезней, холода, голода, воздействия внешней среды и многих других стрессовых факторов, которые можно охарактеризовать как неизбежные составляющие войны. 
Работа О. Юрмана [35] основана на воспоминаниях участника событий времен Гражданской войны в России Франтишека Прудила, солдата Австро-Венгерской армии, воевавшего в Галиции, впоследствии плененного на фронте; его дальнейшая жизнь проходила уже на территории Поволжья, Урала, Сибири и Дальнего Востока. Книга иллюстрирована большим количеством фотодокументов.

Научный интерес представляет дневник бывшего легионера Й. Зимы, в котором участник и свидетель тех событий описывает свою повседневную жизнь, мысли, размышления в период с 1914 по 1920-е годы [38]. В приложении книги присутствуют личные документы Й. Зимы, свидетельство о рождении, свидетельство о браке, о смерти, фотографии, оттиски рукописей и т. д.

Интересна также работа Ф. Эммерта [33], снабженная большим количеством фотодокументов, которые наглядно иллюстрируют сцены жизни чешских легионеров не только в России, но и в Европе (Франция, Италия).

Весной 1918 г. несколько десятков эшелонов чехословацкого корпуса перемещались в Сибирь из Европейской части России. Конечным объявленным пунктом был Владивосток. По официальной версии руководство чехословацкого корпуса заявляло о своем желании отправиться на морском транспорте на французский фронт для оказания помощи войскам Антанты. В этот период Казанский Совет Комиссаров известил центральные органы о перемещении из Иркутска в Восточную Сибирь до 66 эшелонов чешских легионеров. У советского руководства возникло подозрение в контрреволюционности легионеров этих и других эшелонов. Так, дополнительно ожидалось перемещение чешских эшелонов через Сызрань в Сибирь.

В указанный период уездный город Симбирской губернии Сызрань являлся одной из крупнейших железнодорожных станций, расположенных на стыке магистральных путей, соединяющих европейские регионы России с ее восточными провинциями. Советское руководство актуализировало задачу разоружения вновь проходящих через Сызрань чешских эшелонов. Поэтому 30 мая 1918 г. заместитель председателя Совета Народных Комиссаров А.И. Рыков от имени правительства телеграфировал Сызранскому Совету требование остановить и разоружить чешские эшелоны. Рыков приказывал все действия Сызранского исполнительного комитета согласовывать с московским и местным (губернским) руководством. Дополнительно председатель Симбирского совета комиссаров М.А. Гимов рекомендовал по возможности отправлять чешские эшелоны в Архангельск [25].

Весной 1918 г. в Пензе также произошел конфликт между чехословацкими легионерами и красногвардейскими отрядами. Концентрация огромной массы дисциплинированных чехословацких войск на огромном территориальном пространстве представляла угрозу для Советской власти, имевшей сильную оппозицию в местной среде. Очевидно, в этот период чехословацкие лидеры имели тайные и явные контакты с представителями различных политических сил и движений, заинтересованных в использовании чехословацких войск.

Очевидцы событий в разных версиях интерпретировали причину восстания чехословаков. Так, например, в начале $1920-х$ гг. один из участников установления Советской власти в Пензенском крае И. Шапиро на страницах газеты «Трудовая правда» изложил официальную версию трактовки причин чехословацкого восстания [31]. Согласно его версии, чехословацкие лидеры, заинтересованные в продолжении борьбы с Германией, обратились к Советскому правительству с просьбой отправить чехословаков на французский фронт. По мнению автора, один из лидеров чешского национального движения и создателей чехословацкого корпуса Т.Г. Масарик зачислил корпус в состав французской армии. Перемещению чехословаков помешала делегированная в Россию французская военная миссия, вступившая в переговоры с чешским командованием. «...У генералов и банкиров нашелся общий язык, и чехи были проданы», - резюмировал автор статьи. И. Шапиро имел в виду соглашение между чешским командованием и французской стороной, поддержанное местными противниками большевиков, о начале военных действий против Советской власти. По мнению автора, дислоцированным в Киеве чешским войскам было предписано двинуться в Архангельск, на соединение с английскими войсками для борьбы с Красной Армией. Но вмешательство чехос- 
ловацких коммунистов частично сорвало этот план. Только несколько эшелонов отправились в Архангельск. Один чешский полк перешел в Красную Армию (отметим, что крупное военное красное подразделение чехов находилось в Пензе), и еще один полк остался на Дону.

Кризисная ситуация могла привести к разложению частей. Пензенский Совет предложил чехам сдать оружие. В ответ 28 мая 1918 г. чехословацкие войска под командованием С. Чечека начали наступление на Пензу. 29 мая чешские части под командованием поручика Й.И. Швеца ворвались в город [31]. Чешский красный отряд, как и красногвардейские части, был разгромлен. Согласно уточненным современным данным пензенского историка А.Г. Шарикова, при обороне Пензы погибло 300 красноармейцев, в том числе 128 чехов и словаков 1-го советского чехословацкого полка [32, с. 34].

В 1920-1930-х гг. в периодической печати публиковались воспоминания участников пензенских событий. После внимательного прочтения публикаций можно сделать вывод, что данные статьи носили идеологический характер и подчинялись общему клише. Участник событий В. Орлов в 1920 г. поделился собственными воспоминаниями. По его сведениям, к арестованным красногвардейцам обращались чешские офицеры, агитировавшие объединить усилия в борьбе с Германией. Чехословацкое присутствие в Пензе продолжалось недолго, и уже через несколько дней чехи вынуждены были покинуть Пензу [15]. Таким образом, можно говорить, что в восприятии чешских солдат их действия носили антигерманский характер.

В статье И. Лодеровского также изложена версия чехословацкого выступления. Согласно его версии, инициаторами восстания явились правые эсеры и их сторонники. Он высказывал мысль о подготовленности восстания, лидеры которого пытались использовать любые причины для его разжигания [13].

По сведениям Н. Ильина, автора еще одной статьи, посвященной рассматриваемым событиям, в составе немногочисленного Пензенского советского гарнизона числилась интернациональная рота мадьяр. Данный факт косвенно подтверждает наличие этнических противоречий между военнопленны- ми на территории региона. В определенной мере этнический фактор взаимной неприязни предполагал поляризацию бывших военнопленных. То есть в 1918 г., в период всеобщей неразберихи и тенденциозности информационной пропаганды, чехословаки с одной стороны и мадьяры с немцами с другой стороны дислоцировались в оппозиционных лагерях [10]. Отметим и наличие в Пензе указанного выше красного чешского отряда, что обостряло ситуацию.

В периодической печати также выделялись экономические аспекты участия чехословаков в вооруженном восстании. Так, например, в обнаруженной в Самарском архиве газетной вырезке статьи «Как это было», со ссылкой на признание члена Учредительного собрания и одного из инициаторов Самарского переворота эсера И.М. Бруншвита, отмечался факт попыток пензенской буржуазии уговорить полковника Чечека оставить чешские части в городе в обмен на 2 млн рублей [6].

В другой газетной вырезке статьи «Пенза 27-30 мая 1918 года» указывалось на факт оплаты представителями буржуазных кругов пребывания чехов, по 30 рублей в сутки. В статье сообщается о том, что позднее в Чехословакии был создан «Легионер-банк», финансовую основу которого составили вывезенные из России денежные накопления чехословацких офицеров и солдат. В этой же статье автор публикации представил факты противоречий между чехами, мадьярами и немцами [7].

Большевики использовали идеологические ресурсы для противостояния врагам Coветской власти. Неоднократно в средствах массовой информации печатались воззвания и обращения к крестьянам, рабочим и представителям национальных групп. Обращения адресовались чехословацким легионерам, они тиражировались в виде листовок для передачи местному населению и солдатам вражеских армий. В разгар боев в зоне дислокации чехословацких частей получило распространение обращение солдат Железной и Пензенской дивизий: «Товарищи чехо-словаки и польские легионеры!». Формулировка названия фиксирует факт присутствия определенного количества этнических поляков в составе чехословацкого легиона. Составители лис- 
товки акцентировали внимание солдат легиона на революционной ситуации в Восточной Европе, необходимость присутствия там пролетариев и крестьян-легионеров для борьбы с эксплуататорскими классами: «...вы все можете ехать на Родину, защищать и укреплять свою революцию» [4]. Авторы воззвания апеллировали к приказу наркома по военным и морским делам Л.Д. Троцкого и решениям ВЦИКа, регламентировавшим возможность беспрепятственного выезда чехов и поляков из Советской России в случае сдачи ими оружия. Приводились примеры отправления отдельных групп легионеров за пределы Советской России при выполнении данного условия. Пребывание чехов в Пензе носило кратковременный характер, но оказало влияние на ситуацию в близлежащих регионах, в том числе в Сызрани.

Именно с целью предотвращения новых военных конфликтов на пути следования чехословаков советским правительством ставилась задача установления с ними мирных отношений. В конце мая 1918 г. состоялись переговоры между представителями чехословаков в лице секретаря Исполнительного Комитета чехословацких войск В. Фундачика и главного исполнительного комиссара Я. Индры с одной стороны и членами чрезвычайной комиссии Сызранского исполнительного комитета С. Бугровым, В. Бубиновым, Н. Сальновым, А. Гросновым, под руководством председателя Сызранского исполкома С. Щербакова, с другой стороны. Переговоры завершились подписанием 30 мая 1918 г. договора Сызранского совета с чехословаками. Он состоял из 10 пунктов, в нем регламентировались права и обязанности чехословаков, перемещающихся из центральных регионов России во Владивосток [8].

В данном ракурсе актуализируется ряд проблем, которые требуют определенных уточнений. В частности, акцентируется роль и значимость Сызранского исполнительного комитета применительно к другим административно-территориальным субъектам по пути следования чехословаков, так как в этом договоре официально регламентировались действия чехословаков на территории не только Сызрани и Сызранского уезда, входивших в юрисдикцию Сызранского исполнительного комитета, но и других губерний, во главе которых находились другие административные органы. Весьма логичен вопрос соотношения действий руководства Сызранского исполнительного комитета с общей политической доктриной центрального Советского руководства. Теоретически, существовала жесткая иерархия и соподчиненность, в данном случае Сызранского совета вышестоящим структурам, представлявшим волю центральных органов. Насколько в данном эпизоде Сызранский исполнительный комитет контролировался вышестоящими структурами, выполняли ли сызранские товарищи какие-либо официальные инструкции или исходили из собственного видения ситуации и дальнейшего прогнозирования передвижения чехословаков? Ответы на данные вопросы важны для понимания юридической силы подписанного в Сызрани договора и возможности его распространения на действия советских административных структур и чехословаков в процессе их перемещения за пределами Сызранского уезда. Уже в первом пункте оговаривались условия невмешательства чехословацких отрядов во внутренние дела «совдепов Российской Федеративной республики» вплоть до Владивостока. Фактически по этому пункту Сызранский исполнительный комитет выступал если не от имени центральных органов власти Советской республики, то по их прямому поручению.

В данном контексте весьма логично звучит второй пункт договора, согласно которому Сызранский исполнительный комитет, с целью снятия с чехословаков обвинения в контрреволюционной деятельности, взял на себя обязанности реабилитации их перед центральными местными властями, по пути следования, и гарантировал сообщение по телеграфу ходатайства беспрепятственного продвижения чехословацких эшелонов до места назначения.

В третьем пункте прописывалось, что чехословаки обязывались сдать перед отъездом все лишнее оружие, которое они изъяли в Пензе, Кузнецке и Сызрани, своим представителям. Данные представители оставались в Сызрани до момента ухода последнего эшелона, а затем обязывались сдать это оружие советским властям. О выполнении этого пункта договора отправлялись телеграммы в центр и по линии передвижения чехословаков 
для информирования руководства на местах. По прибытию во Владивосток чехословаки обязывались сдать Владивостокскому совету рабочих, солдатских и крестьянских депутатов все остальное оружие, не сданное ими в Сызрани, за исключением холодного и карманного.

В пятом пункте Сызранский исполнительный комитет и чехословаки обязывались с целью предотвращения вооруженных выступлений сообща поддерживать порядок, пока не будут сформированы совместные патрули, по равному количеству представителей от каждой стороны.

В шестом пункте регламентировалась численность членов Совета рабочих, солдатских и крестьянских депутатов и чехословаков для информирования и координирования действий: по три человека с каждой стороны.

По седьмому пункту все переговоры с центром и Советом рабочих, солдатских и крестьянских депутатов и чехословацким штабом по поводу возможных конфликтов должны проходить с одобрения двух сторон.

Согласно восьмому пункту чехословаки обязывались пропускать представителей Совета в занятый ими винный склад, в случае его оставления, а также небольшой вооруженный отряд для охраны после его оставления.

В девятом пункте официально прописывалось обязательство чехословаков всеми мерами содействовать нормальному функционированию железнодорожных сообщений по всей линии следования.

Десятый пункт являлся идеологическим по своей сути и декларировал взаимную поддержку чехов, словаков и русских в борьбе с империализмом и оказание взаимной помощи.

Следует отметить факт использования в этом документе обращения «товарищ», «товарищи» со стороны Сызранского исполкома к чехословацким представителям [25].

Дальнейшие действия развивались стремительно. В день подписания договора с чехословаками, в 14 часов, был взорван железнодорожный мост на 272-й версте перегона Забровка - Сызрань, вследствие чего оказалось парализовано движение поездов. В телеграмме председателю Симбирского совета комиссаров М.А. Гимову с сообщением о взрыве отмечалось нежелание чехословацкой охраны допускать рабочих к исправлению повреждений [27].

Таким образом, только что подписанный договор фактически был сорван. А вслед за этим начинается новый этап восстания чехословаков. Риторика и действия местных властей меняются. 1 июня 1918 г. Военно-революционный штаб Симбирска выступил с обращением к населению. В нем восставшие чехословаки именовались как «чехо-словацкие банды». По постановлению Военно-революционного штаба с 00 часов 1 июня Симбирск и Симбирская губерния переводились на военное положение. Выход граждан на улицу после 22.00 воспрещался. Граждане, имеющие не разрешенное к ношению оружие, обязаны были сдать его властям в течение 24 часов. Чрезвычайной комиссии по борьбе с контрреволюцией делегировалось право проводить расстрелы грабителей, хулиганов и лиц, имевших оружие без соответствующего разрешения. В объявлении о введении военного положения в Симбирске и Симбирской губернии отмечалось право советских властей самым жестоким образом подавлять любую контрреволюционную деятельность [14].

Советское правительство отреагировало на события в Симбирской губернии и в других регионах, в которых дислоцировались чехословацкие части. 13 июня 1918 г. главнокомандующим войсками, действовавшими против чехословацкого легиона, был назначен М.А. Муравьев. Одновременно создавался Революционный военный совет фронта, в состав которого помимо М.А. Муравьева вошли на правах политических комиссаров П.А. Кобозев и Г.И. Благонравов. Все советские учреждения обязывались оказывать всемерное содействие Революционному совету фронта во всех его действиях, направленных на подавление мятежа. Неподчинение Революционному военному совету официально декларировалось как измена, с соответствующим наказанием по законам военного времени [29].

Разрастание угрозы военного противостояния чехословаков и советских отрядов ухудшило ситуацию в огромном регионе. С целью локализации чехословацкого движения на местах усилилось движение по мобилизации ресурсов на подавление мятежа. По инициативе Симбирских властей в июне 
1918 г. в Симбирске прошло общее собрание организаций иностранных революционных социалистических рабочих и крестьян Симбирской губернии. Один из участников собрания выступил с речью в память об убитом в том же месяце в Петрограде видном большевистском деятеле В. Володарском. По официальным сводкам на собрании присутствовали представители от мадьяр, русских, чехов, словаков и других национальностей. Участники собрания заявили: «...смерть русского товарища еще большей ненавистью зажжет сердца против врагов русского пролетариата и еще теснее соединит нас с ним». На собрании была принята резолюция, в содержательной части которой заключался призыв к объединению рабочих и крестьян всех национальностей в борьбе против контрреволюции [18]. На собрании был сформирован Исполнительный комитет интернационалистов в составе председателя Орста, заместителя председателя - Валхара, секретаря Гурко и кассира Самовой [21].

26 июня 1918 г. совместными усилиями чехословаков и антисоветски настроенных казаков после трехдневных боев был захвачен Бузулук. На следующий день Бузулукской городской думой было опубликовано воззвание к населению города Бузулука. Население информировалось о том, кто такие чехословаки. Был представлен общий обзор истории чехословаков, отмечался феномен добровольной сдачи чехословаков российским войскам в годы Первой мировой войны. Причины их сдачи в плен подавались как желание чехословаков сражаться в российской армии против немцев и мадьяр. При Временном правительстве продолжался динамичный процесс формирования чехословацких подразделений, но политика большевиков, ориентированная на союз с Германией, повлияла на статус чехословаков. Авторы воззвания апеллировали к факту тайных переговоров между большевиками и Германией, одним из пунктов которых было уничтожение чехословацких отрядов. Основная мысль воззвания заключалась в том, что чехословацкие легионеры выполняют освободительную миссию, добывая с оружием в руках свободу себе и русским людям в борьбе против большевиков. В воззвании излагался так- же план восстановления России. В частности, высшим органом должно было стать Учредительное собрание [2].

Несомненно, часть населения Бузулука, равно как и многих других населенных пунктов, ожидала прихода чехословаков и казачьих формирований. Так, уже 26 июня 1918 г., в момент входа чехословаков и их союзников в Бузулук, состоялось совещание президиума Городской думы с участием члена Всероссийского учредительного собрания С.И. Цодикова. В три часа дня на городской площади состоялся благодарственный молебен в присутствии большого числа граждан и сбор средств для семей убитых чехословаков и казаков. Также в здании реального училища состоялось собрание военнослужащих, на котором было объявлено о формировании народной армии. На следующий день прошли торжественные похороны убитых чехословацкого солдата и русского офицера. Через несколько дней представители вновь формируемой армии организовали торжественный ужин в местном городском саду для казаков и чехословаков [17]. Данные мероприятия проводились по всем нормам общепринятого этикета по условиям военного времени. Так, в похоронах погибших русского офицера и чеха принимал участие представитель церкви, о чем местный городской голова в официальной записке уведомил регента Троицкого собора [23]. Сама процедура проведения похорон разрабатывалась на заседании комиссии по устройству праздника в честь чехословацких и казачьих войск, освободивших город Бузулук от «большевистских банд». Отметим, что в городе были расстреляны большинство захваченных с оружием и несколько комиссаров.

На Хлебной площади Бузулука по согласованию с командным составом чехословаков и казаков планировалось провести парад. По протоколу должны были выступить с приветственной речью представители городских властей. После парада предполагались спектакль и обед во Фруктовом саду для военных с последующей работой кинематографа. Проработку деталей организации данных мероприятий должны были осуществить член Управы Ф.Е. Глаголев, а также Д.П. Малеин и В.А. Жемчужников. На официальном уровне планировалось устроить грандиозный празд- 
ник, о проведении которого предполагалось оповестить население города. Следует отметить одну важную деталь, связанную с финансированием предстоящего праздника. Городская комиссия приняла решение из нескольких пунктов по сбору финансовых средств. Их планировалось собрать с помощью квартальных представителей, соответственно в городе организовывался так называемый «кружечный сбор». Члены комиссии выработали предложение к владельцам кинематографа и арендаторам Народного дома: отчислять все собранные средства со сборов со зрелищ на устройство этого празднества. Параллельно, в день проведения праздника, предполагался сбор средств с гуляний в городском саду. Определенную часть денег члены комиссии планировали собрать с действующих в городе профессиональных союзов. Также городское и земское самоуправление возлагало на себя определенные финансовые обязательства [20]. Тогда же городской голова от лица Городской управы обратился с ходатайством к заведующему электрической станции «Динамо» с просьбой предоставить электричество в Народный дом в праздничный день для организации спектакля для чехословаков и казачьих войск. Накануне проведения праздника члены комиссии обязывались согласовать свои действия с Городской управой для разработки плана праздника [22].

Вхождение чехословацких войск в Бузулук вызвало положительную реакцию определенной части общественности региона. Это подтверждается различными официальными документами. Например, председатель Бузулукской думы направил в Самару представителю Чехословацкого национального совета доктору Влассоку приветственную телеграмму, в которой отмечалась беззаветная борьба чехословаков за счастье России и славянства против большевиков и немцев. Из телеграммы видно стремление антибольшевистских сил к сближению с чехословаками, как выражение идеи этнического и политического единства в борьбе с большевизмом и враждебной Германией. Собственно, процедура отправки телеграммы свидетельствует о сохранении организационной структуры управления в чехословацких войсках, подразделе- ния которых подчинялись единому центру в лице Чехословацкого национального совета, который воспринимался чехами и словаками как высшая структура [30].

10 июля 1918 г. под ударами белогвардейцев и чехословаков пала Сызрань. В тот же день вышел приказ № 1 по Сызранскому гарнизону командира 4-го чехословацкого полка подпоручика Камиля Францевича Вобратилека. Сызрань объявлялась на осадном положении. Обязанности коменданта города возлагались на прапорщика Ивана Шпале и его помощника капитана Комашинского [19]. Всем гражданам Сызрани предлагалось немедленно арестовывать и передавать коменданту города большевиков и сочувствующих им. В противном случае обвиненные в предательстве могли быть подвергнуты военному полевому суду.

Обращает на себя внимание тот факт, что обязанности командира полка выполнял подпоручик. Это свидетельствует о дефиците или отсутствии офицеров старшего корпуca. Можно предположить, что это объяснялось спецификой лагерного содержания дореволюционного времени, когда офицеры среднего и старшего звена изолировались от рядового состава. Подобные ситуации искусственного роста младших офицеров чехословацких частей сохранялись в ряде других чехословацких подразделений.

Следует отметить высокий уровень дисциплинированности рядовой массы чехословаков, которые, несмотря на отсутствие вышестоящих офицеров, административно-командные функции возложили на офицеров младшего звена, в частности подпоручиков и прапорщиков.

Архивные документы подтверждают факт подчинения капитана Комашинского прапорщику Ивану Шпале. Подобный случай свидетельствует о принципе формирования двойного руководства городов и территорий при участии белогвардейцев и чехословаков. В данных обстоятельствах чехословацкие офицеры выполняли комендантские обязанности русских белогвардейских офицеров.

24 июля 1918 г. за подписью члена коллегии Наркомата по военным делам РСФСР К.К. Юренева всем военным советам и военкомам была отправлена телеграмма, в кото- 
рой заявлялось об объединении чехословаков и белогвардейцев, установивших к этому времени контроль и над Симбирском. В телеграмме отмечалось отсутствие какой-либо угрозы со стороны Германии, поэтому командиры должны быть готовы отправить, в случае получения приказа, на Чехословацкий фронт все имеющиеся на границе с немцами отряды, за исключением застав и охранных частей [28].

Существовала угроза расширения сферы влияния чехословаков, поэтому во всех уездах в зоне соприкосновения с чехословацкими войсками проводились мобилизационные мероприятия. Так, в 20-х числах июля 1918 г. уездный комиссар внутренних дел Карсунского уезда Симбирской губернии Репинский телеграфировал в Москву народному комиссару внутренних дел о проведенной эвакуации советских учреждений и работников и мобилизации членов совдепа и местных большевиков в Красную Армию и создании Коллегии полевого штаба. Члены штаба сообщали о моральном настрое красноармейцев и их клятве оказать отпор врагу [16].

В августе 1918 г. продолжались военные действия, общий накал которых создавал угрозу Советской власти. 30 августа 1918 г. состоялся разговор по прямому проводу между командующим 1-й советской армией М.Н. Тухачевским и одним из ответственных по противостоянию белочешскому мятежу И.М. Варейкисом. Последний откровенно заявлял о невозможности местных красных частей противостоять чехословацким войскам на территории Симбирской губернии. Ссылаясь на данные разведки, Варейкис информировал Тухачевского о передвижении неприятельских сил от Буинска по направлению к Алатырю. Обсуждалась возможность эффективного использования авиации и артиллерии, участия в боевых действиях финнов. В разговоре упоминался главком вооруженных сил РСФСР И.И. Вацетис, обещавший помощь людскими ресурсами [26].

Восстание чехословаков вызвало интерес к ним со стороны оппозиционно настроенных по отношению советской власти общественных кругов, стремившихся установить дружественный морально-психологический климат между чехословаками и местным населением. Одним из элементов подобной идеологической работы являлись публичные встречи с местным населением с различного рода воззваниями и обращениями, авторами которых были известные лидеры антисоветских сил. Так, в разгар чехословацкого мятежа получили распространение листовки агитационного культурно-просветительского отдела Комитета членов Всероссийского Учредительного собрания «Кто такие чехо-словаки и за что они воюют?». Составители листовки апеллировали к рабочим и крестьянам, именуя их «товарищи». Подобное обращение оказалось оправданным по причине крайне низкой политической подготовки выходцев из данных социальных категорий, поляризованных в ходе Гражданской войны. В этом обращении авторы представили краткий экскурс в историю чехов и словаков, акцентируя внимание на их многолетней вассальной зависимости от Австро-Венгерского государства [1].

Авторы листовки подчеркивали созидательную суть Февральской революции в процессе дальнейшей эволюции российского общества. По их мнению, именно февральские события 1917 г. явились предтечей подъема национально-освободительных чувств славянских народов, тяготившихся властью Австро-Венгрии. Поэтому чехословацкий вооруженный корпус в сознании чехов представлялся как единственная реальная сила, способная противостоять австрийской военной машине. Авторы листовки настаивали на необходимости наличия подобной вооруженной силы в лице чехословаков как реального союзника России в борьбе с Австро-Венгрией и Германией. Октябрьский переворот 1917 г. разрушил грядущие перспективы поражения Германии и Австро-Венгрии. По утверждению авторов обращения, политика большевистских руководителей в лице Ленина и Троцкого, заключивших с Германией Брестский мир, определила самостоятельный выбор чехословаков, которые решили отправиться во Францию для борьбы с Германией и Австро-Венгрией. Большевики обещали транспортировать чехословаков во Владивосток с целью их отправки морским путем в дружественные государства. Впоследствии, согласно содержанию обращения, советское руководство совместно с германским правительством обещало разоружить и выдать чехословаков австрийскому 


\section{ОТЕЧЕСТВЕННАЯ ИСТОРИЯ}

правительству; в этом случае их неминуемо ожидала печальная участь. Составители листовки констатировали возмущение чехословаков, восставших с оружием в руках против Советов. Идейная суть этого обращения заключается в этнической солидарности славянских народов. В заключение листовки составители обратились с призывом к товарищам рабочим и крестьянам протянуть чехословакам братскую руку и защищать свои интересы против Германии. Подобные обращения, составленные простым, доступным языком, были рассчитаны на широкие слои населения.

Безусловно, имел место и противоположный процесс. Так, 12 сентября 1918 г. было опубликовано воззвание «Чехословакам, сражающимся против советских войск» председателя Реввоенсовета, военного комиссара по военным и морским делам Троцкого. В характерной для него пафосной манере он обозначил провокационную суть лидеров белогвардейского движения, которые, по его мнению, преступно использовали чехословацких солдат. Троцкий констатировал победу Красной Армии, которая освободила к этому времени Казань и Симбирск. По его прогнозам в ближайшем будущем планировалось взятие Екатеринбурга, Самары и других городов, в которых также располагались чехословацкие гарнизоны. В воззвании особо отмечалось обещание советского руководства по отношению к добровольно сдавшимся чехословакам: «Торжественно перед лицом рабочего класса всех стран объявляю Вам: всякий чехословатский солдат, который добровольно сдаст оружие, будет помилован и получит возможность свободно жить в России наравне со всеми другими трудящимися гражданами Советской Республики» [5].

В это же время тиражировались обращения к солдатам различных национальных групп с призывом вступить в Красную Армию. Например, оперативная часть штаба армии Южной республики выпустила листовку «Солдаты чехи, словаки, сербы, словенцы, хорваты, поляки, румыны», в которой говорилось следующее: «Все, кому дороги идеи русской революции, записывайтесь в ряды образцовых и дисциплинированных советских войск» [3]. Данное воззвание выполняло пропагандистскую миссию, ориентированную на умонастроение военнопленных, многие из которых весьма смутно представляли свое будущее в годы Гражданской войны и задумывались о дальнейших перспективах выезда за рубеж или проживания в государстве при неизвестном результате военной неразберихи. Очевидно, определенная часть этих военнопленных не питала каких-либо иллюзий относительно возможности беспрепятственного выезда из растерзанной Гражданской войной России, и только участие на стороне какойлибо из враждующих сил в качестве военнослужащих в определенной мере могло способствовать их выезду на этническую родину. Поэтому многие военнослужащие находились на распутье, возможно по идеологическим убеждениям: либо как можно скорее уехать из России, либо остаться на новой родине.

В заключение хотелось бы отметить, что история Чехословацкого легиона являлась объектом исследования многих ученых. Проблема взаимоотношения чехословаков с представителями различных политических сил, которые боролись за власть в стране, является достаточно актуальной. Отношение рядовых граждан и администрации зависело от уровня их политической подготовки, собственных политических умонастроений и предпочтений. Поэтому отношение к чехословакам в России до сих пор является противоречивым: одни граждане считают их жертвами войны, другие же более категоричны в суждениях. Сами чехи в своем многообразии были также поляризованы друг от друга по политическим мотивам, но все же большая часть из них просто вынуждена была находить компромисс с большевиками и представителями Временного правительства для того, чтобы возвратиться домой и продолжить борьбу за собственную независимость и формирование государства.

\section{ПРИМЕЧАНИЕ}

1 Данная статья была подготовлена в рамках проекта Моравско-Силезского края «Поддержка талантливых аспирантов Остравского университета», финансируемого из бюджета MSK (04544/2017/ RRC)».

This article was prepared as part of the project of the Moravian-Silesian Region "Support of talented postgraduate students of the University of Ostrava", financed by the MSK budget (04544/2017/RRC). 


\section{СПИСОК ЛИТЕРАТУРЫ}

1. Агитационная листовка «Кто такие чехословаки и за что они воюют» // Государственный архив Оренбургской области. - Ф. 275. - Оп. 1. Д. 16а. - Л. 157.

2. Воззвание к населению города Бузулука // Государственный архив Оренбургской области. Ф. 275. - Оп. 1. - Д. 16а. - Л. 35.

3. Воззвание «Солдаты чехи, словаки, сербы, словенцы, хорваты, поляки, румыны» // Ульяновский архив новейшей истории. - Ф. 1. - Оп. 1. Д. 302. - Л. 6.

4. Воззвание «Товарищи чехо-словаки и польские легионеры» // Ульяновский архив новейшей истории. - Ф. 57. - Оп. 1. - Д. 241. - Л. 3.

5. Воззвание «Чехословакам, сражающимся против советских войск» // Ульяновский архив новейшей истории. - Ф. 1. - ОП. 1. - Д. 302. - Л. 5.

6. Вырезка газетной статьи «Как это было» // Центральный государственный архив Самарской области. - Ф. Р 636. - Оп. 2. - Д. 27. - Л. 9.

7. Вырезка газетной статьи «Пенза 27-30 мая 1918 года» // Центральный государственный архив Самарской области. - Ф. Р 636. - Оп. 2. Д. 27. - Л. 10.

8. Договор между Сызранским Советом и чехословацким командованием // Ульяновский архив новейшей истории. - Ф. 57. - Оп. 1. - Д. 309. - Л. 2-3.

9. Драгомирецкий, В. С. Чехословаки в России. 1914-1920 / В. С. Драгомирецкий. - Париж ; Прага : [Б. и.], 1928. - III, 219, [7] с.

10. Ильин, Н. 10-я годовщина боя с чехо-словаками в Пензе / Н. Ильин // Трудовая правда. - 1928. № 151 .

11. Каржанский, Н. С. Чехословаки в России: По неизданным официальным документам / Н. С. Каржанский (Качанов). - М. : Змій, 1918. - 95 с.

12. Клеванский, А. Х. Чехословацкие интернационалисты и проданный корпус: Чехословацкие политические организации и воинские формирования в России. 1914-1921 гг. / А. Х. Клеванский. М. : Наука, 1965. - 397 с.

13. Лодеровский, И. Семь лет назад. В бою с чехословаками / И. Лодеровский // Трудовая правда. -1925 . - № 117.

14. Объявление о введении военного положения в Симбирске и в Симбирской губернии // Ульяновский архив новейшей истории. - Ф. 57. - Оп. 1. Д. 309. - Л. 6-7.

15. Орлов, В. В борьбе с чехами / В. Орлов // Трудовая правда. - 1920. - № 119.

16. Отчет наркому внутренних дел от Карсунской уездной организации РКП в борьбе с чехословаками // Ульяновский архив новейшей истории. Ф. 57. - Оп. 1. - Д. 309. - Л. 45.
17. Памятка // Государственный архив Оренбургской области. - Ф. 275. - Оп. 1. - Д. 16а. - Л. 1.

18. Под знаменем интернационализма // Известия Симбирского вестника. - 1918. - 4 июня.

19. Приказ № 1 по Сызранскому гарнизону от 10 июля 1918 г. // Ульяновский архив новейшей истории. - Ф. 1. - Оп. 1. - Д. 302. - Л. 6.

20. Протокол заседания комиссии по устройству праздника в честь чехословацких и казаческих войск // Государственный архив Оренбургской области. - Ф. 275. - Оп. 1. - Д. 16а. - Л. 46.

21. Протокол общего собрания иностранных рабочих и крестьян // Ульяновский архив новейшей истории. - Ф. 57. - Оп. 1. - Д. 309. - Л. 36-37.

22. Прошение заведующему электрической станцией «Динамо» // Государственный архив Оренбургской области. - Ф. 275. - Оп. 1. - Д. 16а. - Л. 33.

23. Регенту Троицкого собора // Государственный архив Оренбургской области. - Ф. 275. - Оп. 1.Д. 16a. - Л. 28.

24. Савваитова, М. Д. Чешский вопрос в русском общественном мнении в период Первой мировой войны (1914 - октябрь 1917 года) : дис. ... канд. ист. наук : 07.00.02 / Савваитова Мария Дмитриевна. - М., 1993. $-231 \mathrm{c}$.

25. Сообщение Председателя Совета Комиссаров Гимова // Ульяновский архив новейшей истории. -Ф. 57. - Оп. 1. - Д. $309-$ Л. 1.

26. Стенограмма разговора Тухачевского и Варейкиса по прямому проводу // Ульяновский архив новейшей истории. - Ф. 57. - Оп. 1. - Д. 309. Л. 52-53.

27. Телеграмма Гимову о взрыве моста чехословацкими войсками // Ульяновский архив новейшей истории (УАНИ). - Ф. 57. - Оп. 1. - Д. 309. - Л. 4.

28. Телеграмма о взятии Симбирска // Ульяновский архив новейшей истории. - Ф. 57. - Оп. 1.Д. 309. - Л. 44.

29. Телеграмма о назначении Муравьева главнокомандующим войсками // Ульяновский архив новейшей истории. - Ф. 57. - Оп. 1. - Д. 309. - Л. 17.

30. Телеграмма представителю Чехословацкого национального совета доктору Влассоку // Государственный архив Оренбургской области. Ф. 275. - Оп. 1. - Д. 16а. - Л. 173.

31. Шапиро, И. Годовщина / И. Шапиро // Трудовая правда. - 1920. - № 119.

32. Шариков, А. Г. Белочешский мятеж в Пензе глазами очевидцев / А. Г. Шариков // Краеведение. - 1997. - № 1. - С. 34-38.

33. Emmert, F. Českoslovenští legionáři za první světové války / F. Emmert. - Praha : Mladá fronta, 2014. $-220 \mathrm{~s}$.

34. Fic, V. M. Československé legie v Rusku a boj za vznik Československa 1914-1918 / V. M. Fic. - Brno : Stilus Press, 2014. - IV díl. -512 s. 
35. Jurman, O. Legionářská odysea. Z Čech až do Vladivostoku / O. Jurman. - Praha : Vydavatelství: Brána, 2016. - $208 \mathrm{~s}$.

36. Vácha, D. Bratrstvo. Všední a dramatické dny československých legií v Rusku 1914-1918 / D. Vácha. Praha: Nakladatelství EPOCHA, 2012. -336s.

37. Vácha, D. Ostrovy v bouři. Každodenní život československých legií v ruské občanské válce (19181920) / D. Vácha. - Praha : Nakladatelství EPOCHA, 2016. $-440 \mathrm{~s}$.

38. Zima, J. Zima v Rusku. Zápisky českého legionáře/ J. Zima. - Praha : Omnibooks, 2013. - 104 s.

\section{REFERENCES}

1. Agitatsionnaya listovka «Kto takie chekhoslovaki i za chto oni voyuyut» [Agitation Leaflet "Who are Czechoslovaks and What They Are Fighting for"]. Gosudarstvennyy arkhiv Orenburgskoy oblasti [State Archive of the Orenburg Region], F. 275, Op. 1, D. 16a, L. 157.

2. Vozzvaniye k naseleniyu goroda Buzuluka [Appeal to the Population of the City of Buzuluk]. Gosudarstvennyy arkhiv Orenburgskoy oblasti [State Archive of the Orenburg Region], F. 275, Op. 1, D. $16 a$, L. 35.

3. Vozzvaniye «Soldaty chekhi, slovaki, serby, sloventsy, khorvaty, polyaki, rumyny» [Appeal "Soldiers Czechs, Slovaks, Serbs, Slovenes, Croats, Poles, Romanians"]. Ulyanovskiy arkhiv noveyshey istorii [Ulyanovsk Archive of Modern History], F. 1, Op. 1, D. 302, L. 6.

4. Vozzvaniye «Tovarishchi chekho-slovaki i polskiye legionery» [Appeal "Comrades Czechoslovaks and Polish Legionaries"]. Ulyanovskiy arkhiv noveyshey istorii [Ulyanovsk Archive of Modern History], F. 57, Op. 1, D. 241, L. 3.

5. Vozzvaniye «Chekhoslovakam, srazhayushchimsya protiv sovetskikh voysk» [Appeal to the Czechoslovaks Fighting Against the Soviet Troops]. Ulyanovskiy arkhiv noveyshey istorii [Ulyanovsk Archive of Modern History], F. 1, Op. 1, D. 302 , L. 5.

6. Vyrezka gazetnoy statyi «Kak eto bylo» [Fragment of the Newspaper Article "How It Was"]. Tsentralnyy gosudarstvennyy arkhiv Samarskoy oblasti [Central State Archive of the Samara Region], F. R 636, Op. 2, D. 27, L. 9.

7. Vyrezka gazetnoy statyi «Penza 27-30 maya» [Fragment of the Newspaper Article "Penza on May 27 30"]. Tsentralnyy gosudarstvennyy arkhiv Samarskoy oblasti [Central State Archive of the Samara Region], F. R 636, Op. 2, D. 27, L. 10.

8. Dogovor mezhdu Syzranskim Sovetom i chekhoslovatskim komandovaniyem [Treaty Between the Syzran Council and the Czechoslovak Command]. Ulyanovskiy arkhiv noveyshey istorii [Ulyanovsk Archive of Modern History], F. 57, Op. 1, D. 309, L. 2-3.

9. Dragomiretskiy V.S. Chekhoslovaki v Rossii. 1914-1920 [Czechoslovaks in Russia. 1914-1920]. Paris; Prague, 1928. 219 p.

10. Ilyin N. 10-ya godovshchina boya s chekhoslovakami v Penze $\left[10^{\text {th }}\right.$ Anniversary of the Battle with the Czechoslovaks in Penza]. Trudovaya Pravda [Labour Truth], 1928, no. 151.

11. Karzhanskiy N.S. Chekhoslovaki v Rossii: Po neizdannym ofitsialnym dokumentam [Czechoslovaks in Russia: According to Unpublished Official Documents]. Moscow, Zmiy Publ., 1918. 95 p.

12. Klevanskiy A.Kh. Chekhoslovatskiye internatsionalisty $i$ prodannyy korpus: Chekhoslovatskiye politicheskiye organizatsii i voinskiye formirovaniya v Rossii. 1914-1921 gg. [Czechoslovak Internationalists and Sold Corps: Czechoslovak Political Organizations and Military Formations in Russia. 1914 1921]. Moscow, Nauka Publ., 1965. 397 p.

13. Loderovskiy I. Sem let nazad. V boyu s chekhoslovakami [Seven Years Ago. In Battle with the Czechoslovaks]. Trudovaya Pravda [Labour Truth], 1925, no 117.

14. Obyavleniye o vvedenii voennogo polozheniya v Simbirske i v Simbirskoy gubernii [Announcement on Imposing Martial Law in Simbirsk and in Simbirsk Province]. Ulyanovskiy arkhiv noveyshey istorii [Ulyanovsk Archive of Modern History], F. 57, Op. 1, D. 309, L. 6-7.

15. Orlov V.V borbe s chekhami [In the Fight Against the Czechs]. Trudovaya Pravda [Labour Truth], 1920, no. 119.

16. Otchet narkomu vnutrennikh del ot Karsunskoy uyezdnoy organizatsii RKP v borbe s chekhoslovakami [Report to the People's Commissar of Internal Affairs from the Karsun County Organization of the RCP in the Struggle Against the Czechoslovaks]. Ulyanovskiy arkhiv noveyshey istorii [Ulyanovsk Archive of Modern History], F. 57, Op. 1, D. 309, L. 45.

17. Pamyatka [Memo]. Gosudarstvennyy arkhiv Orenburgskoy oblasti [State Archive of the Orenburg Region], F. 275, Op. 1, D. 16a, L. 1.

18. Pod znamenem internatsionalizma [Under the Banner of Internationalism]. Izvestiya Simbirskogo vestnika, 1918, 4 June.

19. Prikaz № 1 po Syzranskomu garnizonu ot 10 iyulya 1918 g. [Order 1 of the Syzran Garrison of July 10, 1918]. Ulyanovskiy arkhiv noveyshey istorii [Ulyanovsk Archive of Modern History], F. 1, Op. 1, D. 302, L. 6.

20. Protokol zasedaniya komissii po ustroystvu prazdnika $\mathrm{v}$ chest chekho-slovakskikh i kazacheskikh voysk [Minutes of the Meeting of the Commission for Holiday Organization in Honor of the Czechoslovak 
and Cossack Troops]. Gosudarstvennyy arkhiv Orenburgskoy oblasti [State Archive of the Orenburg Region], F. 275, Op. 1, D. 16a, L. 46.

21. Protokol obshchego sobraniya inostrannykh rabochikh i krestyan [Minutes of the General Meeting of Foreign Workers and Peasants]. Ulyanovskiy arkhiv noveyshey istorii [Ulyanovsk Archive of Modern History], F. 57, Op. 1, D. 309, L. 36-37.

22. Proshenie zaveduyushchemu elektricheskoy stantsiyey «Dinamo» [A Petition to the Head of the Electric Power Station Dynamo]. Gosudarstvennyy arkhiv Orenburgskoy oblasti [State Archive of the Orenburg Region], F. 275, Op. 1, D. 16a, L. 33.

23. Regentu Troitskogo sobora [To the Regent of the Trinity Cathedral]. Gosudarstvennyy arkhiv Orenburgskoy oblasti [State Archive of the Orenburg Region], F. 275, Op. 1, D. 16a, L. 28.

24. Savvaitova M.D. Cheshskiy vopros v russkom obshchestvennom mnenii v period Pervoy mirovoy voyny (1914-oktyabr 1917 goda): dis. ... kand. ist. nauk [The Czech Issue in the Russian Public Opinion During the First World War (1914 - October 1917). Cand. hist. sci. diss.]. Moscow, 1993. 231 p.

25. Soobshchenie Predsedatelya Soveta Komissarov Gimova [Message of Chairman of the Council of Commissars Gimov]. Ulyanovskiy arkhiv noveyshey istorii [Ulyanovsk Archive of Modern History], F. 57, Op. 1, D. 309, L. 1.

26. Stenogramma razgovora Tukhachevskogo i Vareykisa po pryamomu provodu [Transcript of Telephone Conversation Between Tukhachevsky and Vareikis]. Ulyanovskiy arkhiv noveyshey istorii [Ulyanovsk Archive of Modern History], F. 57, Op. 1, D. 309, L. 52-53.

27. Telegramma Gimovu o vzryve mosta chekhoslovatskimi voyskami [A Telegram to Gimov about the Explosion of the Bridge by the Czechoslovak Troops]. Ulyanovskiy arkhiv noveyshey istorii [Ulyanovsk Archive of Modern History], F. 57, Op. 1, D. 309, L. 4.

28. Telegramma o vzyatii Simbirska [Telegram on the Capture of Simbirsk]. Ulyanovskiy arkhiv noveyshey istorii [Ulyanovsk Archive of Modern History], F. 57, Op. 1, D. 309, L. 44.
29. Telegramma o naznachenii Muravyeva glavnokomanduyushchim voyskami [A Telegram about the Appointment of Muravyev as Commanderin-Chief of the Troops]. Ulyanovskiy arkhiv noveyshey istorii [Ulyanovsk Archive of Modern History], F. 57, Op. 1, D. 309, L. 17.

30. Telegramma predstavitelyu Chekhoslovatskogo natsionalnogo soveta doktoru Vlassoku [Telegram to the Representative of the Czechoslovak National Council, Doctor Vlassok]. Gosudarstvennyy arkhiv Orenburgskoy oblasti [State Archive of the Orenburg Region], F. 275, Op. 1, D. 16a, L. 173.

31. Shapiro I. Godovshchina [Anniversary]. Trudovaya pravda [Labour Truth], 1920, no. 119.

32. Sharikov A.G. Belocheshskiy myatezh v Penze glazami ochevidtsev [Revolt of the Czechoslovak Legion in Penza According to Eyewitnesses]. Kraevedenie, 1997, no 1, pp. 34-38.

33. Emmert F. Českoslovenští legionáři za první světové války [Czechoslovak Legionaries during the First World War]. Praha, Mladá fronta Publ., 2014. 220 p.

34. Fic V.M. Československé legie v Rusku a boj za vznik Československa 1914-1918. [Czechoslovak Legions in Russia and Struggle for the Emergence of Czechoslovakia in 1914-1918]. Brno, Stilus Press Publ., 2014, Part IV. 512 p.

35. Jurman O. Legionářská odysea. Z Čech až do Vladivostoku. [Legionary Odyssey. from Bohemia to Vladivostok]. Praha, Brána Publ., 2016. 208 p.

36. Vácha D. Bratrstvo. V̌̌ední a dramatické dny československých legii v Rusku 1914-1918. [Brotherhood. Ordinary and Dramatic Days of Czechoslovak Legions in Russia, 1914-1918]. Praha, EPOCHA Publ., 2012.336 p.

37. Vácha D. Ostrovy v bouři. Každodenní život československých legií v ruské občanské válce (19181920). [The Everyday Life of Czechoslovak Legions in the Russian Civil War (1918-1920)]. Praha, EPOCHA Publ., 2016. 440 p.

38. Zima J. Zima v Rusku. Zápisky českého legionáre. [Winter in Russia. Notes of the Czech Legionnaire]. Praha, Omnibooks Publ., 2013. 104 p.

\section{Information about the Author}

Berik K. Dulatov, Master Student, Candidate for a Doctor Degree, Faculty of Philosophy, University of Ostrava (Czech Republic), Reální, 3, 70103 Ostrava, Czech Republic, dulatov_berik@mail.ru, https:/ /orcid.org/0000-0003-2406-508X

\section{Информация об авторе}

Берик Кайратович Дулатов, магистр, докторант философского факультета, Остравский университет, Reální, 3, 70103 г. Острава, Чешская Республика, dulatov_berik@mail.ru, https:// orcid.org/0000-0003-2406-508X 